\title{
Introduction to the Research Handbook on
}

\author{
Fiduciary Law
}

\author{
D. Gordon Smith and Andrew S. Gold
}

Fiduciary law governs myriad relationships, including employment relationships, business organizations, and professional relationships. Fiduciary relationships characteristically have two parties, a fiduciary and a beneficiary, each of which may be an individual, an organization, or a group of individuals or organizations. The fiduciary acts on behalf of the beneficiary. Trustees are fiduciaries for the beneficiaries of the trust. People with managerial power in a business organization - partners, officers, directors, and so forth - are fiduciaries for the owners of the business organization. Professionals like doctors, lawyers, and clergy may be fiduciaries with respect to their patients, clients, and parishioners. Nations can be fiduciaries and so can government officials.

Despite the varied contexts of fiduciary relationships, scholars have sometimes attempted to understand fiduciary law as a branch of contract, tort, or unjust enrichment. Subsuming fiduciary law within these larger headings has always been challenging. For example, while many fiduciary relationships are formed by contracts, fiduciary relationships need not be contractual. Also, the usual compensatory remedies for torts and contracts differ from the restitutionary remedies for breach of fiduciary duty. And whether a person is unjustly enriched may depend on whether the person is a fiduciary, meaning that the reference to unjust enrichment as a defining element of fiduciary law is tautological. Thus, fiduciary law does not sit well as a subcategory of other areas of law.

While the awkward fit of fiduciary law with other major legal categories makes treating fiduciary law as a distinctive field of study appealing, as one might expect with a body of law created, extended, and developed in varied relationship contexts over hundreds of years through thousands of judicial opinions in numerous separate jurisdictions, there is a great deal of contested ground. Indeed, one of our chapters suggests that the development of fiduciary law has resulted in a mix of legal doctrines that are sometimes motivated by efficiency-based reasoning and sometimes by deontological reasoning. In any event, this mix creates substantial - though perhaps not insurmountable - obstacles to a unified explanatory theory of fiduciary law.

Even as we explore various avenues of unification, scholars approach the field from different starting points. In this volume, for example, some scholars, like Julian Velasco, approach the subject by examining fiduciary relationships, reasoning that a clear understanding of the distinction between fiduciary and nonfiduciary relationships can aid in understanding fiduciary duties and fiduciary remedies. Other scholars consider the subject from the opposite perspective, reasoning that a better understanding of fiduciary duties and fiduciary remedies might shed light on the nature of fiduciary relationships. For example, Arthur Laby has claimed that fiduciaries adopt the 


\section{Research handbook on fiduciary law}

goals or ends of a principal and defends this claim against the charge that his "adopting account" may justify the pursuit of morally illicit ends and that fiduciary obligation is not fulfilled by accidental compliance. And Samuel Bray's chapter focuses on punitive damages as an entry to deeper reflection on the nature of the trust relationship.

Regardless of one's starting point, attempts to unify the study of fiduciary law as a distinctive field represent a break from much prior scholarship that treated fiduciary law as a confusing and haphazard collection of relationships and obligations. Many of the chapters in this volume assume the possibility of a unified account of fiduciary law or at least the possibility that one can rationalize aspects of fiduciary law. For example, Evan Criddle expands on his view that the duty of loyalty is necessary under republican legal theory to protect a fiduciary's beneficiaries from domination, and Sung Hui Kim describes ways in which courts regulate the temptation for wrongdoing by fiduciaries through an anti-corruption norm. Matthew Harding does not view trust as essential to all fiduciary relationships, but he suggests that the cultivation of trust should be an important goal in developing fiduciary law.

A complicating factor in the quest for a unified understanding of fiduciary law is that the rules governing fiduciary relationships are not unitary across jurisdictions. While all jurisdictions seem to adhere with varying degrees of fidelity to the "no-conflict rule" (instructing fiduciaries to avoid acting in the face of conflict between their personal interests and their duties to the beneficiaries) and the "no-profit rule" (requiring fiduciaries to account to their beneficiaries for any gain received in furtherance of their fiduciary obligation), some jurisdictions limit the reach of fiduciary law to these proscriptions, while other jurisdictions impose affirmative performance obligations on fiduciaries. Several authors in this volume use jurisdictional diversity as a motivation for thinking more deeply about the nature of fiduciary relationships and fiduciary duties.

The study of fiduciary law is undergoing a renaissance, with scholars representing many national systems contributing important insights. This volume alone includes legal scholars from the United States, Canada, Israel, Australia, and various countries in Europe. Our hope is that these chapters will advance our understanding of the diversity of approaches that constitute modern scholarship on fiduciary law. We turn now to the chapters themselves.

\section{THEORIES OF FIDUCIARY LAW}

Theories of fiduciary law attempt to explain the normative foundations of fiduciary law, the distinguishing features of fiduciary relationships, the requirements of fiduciary loyalty, the theoretical basis for fiduciary law's traditional remedies, and the theoretical basis for fiduciary law's divergent conduct and decision rules. ${ }^{1}$ Several chapters in this volume contribute to the theory of fiduciary law.

For example, fiduciary law can be understood to incorporate republican principles of non-domination. From this perspective, the law seeks to make sure that one person does

1 See Evan J. Criddle, Liberty in Loyalty: A Republican Theory of Fiduciary Law, 95 TeX. L. REv. 993, 1025 (2017). 
not have the ability to arbitrarily exercise her will over another. Evan Criddle builds on this understanding to justify fiduciary law's "mixed messages" - its tendency to adopt a very strict standard of conduct for the duty of loyalty, but a more deferential standard of judicial review. Given a fiduciary's level of discretion regarding the interests of her beneficiaries, the risk of domination in this setting is substantial. Yet, as Criddle notes, fiduciary discretion is not the only potential source of domination; courts may dominate as well. With this in mind, he suggests that deference to fiduciary judgments should hinge on two questions: "(1) whether or not the fiduciary has exercised entrusted discretionary power; and (2) whether the fiduciary or the court is in a better position to resolve the relevant issue in a manner that tracks the principal's intentions and the beneficiary's best interests." Criddle thus offers a cogent new framework for specifying standards of review in fiduciary law.

Andrew Gold's chapter focuses on the methodology used to understand fiduciary law. Commenters often seek to interpret fiduciary relationships or obligations so that they are unified under a single principle, or so that they track widely held moral principles. Gold suggests that both a coherence criterion and a morality criterion are problematic for explanatory theories of fiduciary law. Fiduciary law has shifted over the decades, even centuries, but not in a way that has completely effaced earlier understandings of fiduciary relationships. Law and economics conceptions of loyalty, for example, are now unquestionably incorporated into fiduciary law, yet earlier morality or honor-based understandings of fiduciary loyalty continue to co-exist with these conceptions. This makes a strong coherence criterion difficult to adhere to. And, to the extent a morality criterion is justified by theories of what law claims, the view that law claims to be moral (as opposed to morally binding) is controversial. Gold's chapter offers potential responses to these concerns, including the possibility that fiduciary law is locally coherent.

One of the most fundamental questions regarding fiduciary law is its relationship to trust. Matthew Harding assesses the significance of trust from several angles, recognizing that trust takes multiple forms. Beginning with an inquiry into what trust is, he focuses in on the way trust involves a type of belief in the person who is trusted. Trusting beliefs can be thin (as when we trust that someone will act rationally) or they can be thick (as when we trust a friend to act in our best interests). The thick kind of trust is especially valuable, but it also leads to significant vulnerability. In Harding's view, trust is not essential to fiduciary relationships, and there are cases where trust will be absent. On the other hand, there are also features of fiduciary relationships that make trust likely to develop over time, and this trust will often be a thick type of trust. This likelihood is important in assessing how fiduciary law should be structured. Harding concludes that fiduciary law must balance the importance of trust for fiduciary relationships against the importance of cooperation in the absence of trust.

Julian Velasco aims to contribute to the project of unifying fiduciary relationships under a single principle that is both "intellectually coherent and descriptively accurate." $\mathrm{He}$ is concerned about the "excessive expansion" of fiduciary law, but finds existing descriptions unable to draw appropriate boundaries. Velasco suggests a heat map as a mental model for testing the descriptive accuracy of any single principle. At the core of the map are relationships that are always (or nearly always) fiduciary in nature, and each successive circle comprises relationships that are less often considered fiduciary. 


\section{Research handbook on fiduciary law}

Velasco is attracted to Paul Miller's fiduciary powers theory for its intellectual coherence, but when tested against the heat map, Miller's theory fares less well. Velasco ultimately offers a modification of the fiduciary powers theory that is claimed to satisfy both criteria: coherence and descriptive accuracy.

\section{FIDUCIARY DUTIES}

Although fiduciary relationships arise in varied contexts, they are united by a distinctive obligation of loyalty. The duty of loyalty does not require complete selflessness, but it generally requires that the fiduciary refrain from self-interested behavior that wrongs the beneficiary. Parties in a fiduciary relationship typically strive to align their interests through various contractual mechanisms, but the judicially imposed duty of loyalty is usually viewed as an important supplement to these devices.

Self-interested behavior takes many forms, each of which may harm the beneficiary. One might assume that courts would treat all forms of self-interested behavior under the rubric of the duty of loyalty, but courts often distinguish two broad categories of fiduciary duty - care and loyalty - and evaluate them under different legal standards. Alleged breaches of the duty of care are measured against a negligence standard, whereas alleged breaches of the duty of loyalty are measured against a more exacting standard that varies by jurisdiction. Although both forms of misconduct are selfserving, courts are distinguishing cases involving lack of effort from cases involving calculated advantage taking. As we will see, cases that engage fiduciary duties cover an expansive territory.

In the biblical parable of the talents, three servants are given charge over their master's assets while he is away on a journey. Two of the servants invested the assets and earned substantial returns, but a third servant, purportedly afraid of the master, did not invest the assets but simply put them away for safekeeping. When the master returned and demanded an accounting from the servants, the two servants who invested wisely were rewarded, but the servant who failed to do so was punished. Stephen Bainbridge reads this parable as a story about prescriptive fiduciary duties. The servants are expected not only to preserve the assets but to increase the value of those assets. Exploring the social and legal context of the parable, Bainbridge reveals subtle differences between the two accounts of the parable in Matthew and Luke and suggests that these differences may be illustrative of differences between various national systems of modern fiduciary law. One important lesson from this examination is that representative relationships have the same basic structure and same basic flaws, regardless of time and place.

Much recent scholarship on fiduciary law focuses on fiduciary motivation, and Sung Hui Kim contributes to this stream of research with her chapter on the "anti-corruption norm." Kim describes the no-profit rule in fiduciary law as a manifestation of an anti-corruption norm, which proscribes the use of an entrusted position for selfregarding gain. While this goal of fiduciary law is widely accepted, implementation can be challenging because it is often difficult to know ex post whether a fiduciary's exercise of discretion has been influenced by the possibility of personal gain. As a result, many courts have adopted prophylactic rules to remove the fiduciary from 
temptation. While these prophylactic rules might easily be rationalized as an attempt to protect vulnerable beneficiaries from an elevated risk of harm, courts have come to view a fiduciary's violation of these rules as evidence of betrayal. Kim examines the uneven regulation of temptation in four contexts - bribes and secret commissions, opportunities, renewals and reversions, and confidential information - and observes that the breadth of the anti-corruption norm raises troubling questions about the scope of fiduciary liability.

Arthur Laby has argued that fiduciaries have an obligation to adopt the goals or ends of a principal. In his chapter in this volume, Laby defends this "adopting" account of fiduciary law against a challenge from Stephen Galoob and Ethan Leib, who offer an alternative account of the fiduciary obligation, the "shaping" account. The key feature of the shaping account is the fiduciary's deliberation. According to Galoob and Leib, a fiduciary is loyal only if the principal's interests matter to the fiduciary's deliberation, the interests matter because they are the principal's interests, and the fiduciary will revise her deliberations based on changes in the principal's interests. Galoob and Leib argue that the adopting account may justify the pursuit of morally illicit ends and that fiduciary obligation is not fulfilled by accidental compliance because those obligations require intentionality. Laby offers an insightful examination of these competing accounts and concludes that the adopting account should be understood to disallow pursuit of illicit ends and does not allow for accidental compliance.

A common theme in scholarship on fiduciary law has engaged the debate over enabling versus mandatory rules in fiduciary law. Amir Licht approaches this issue by focusing on information asymmetries between the fiduciary and beneficiary that stem from unobservable and unverifiable information. Information is unobservable when a principal is not capable of evaluating an agent's performance or when the parties to a fiduciary relationship cannot even imagine future contingencies, and information is unverifiable when a third party (for example, a judge) cannot evaluate evidence of a breach of duty. When a fiduciary has information that is unobservable and unverifiable by the beneficiary, the fiduciary gains power over the beneficiary. The beneficiary might avoid this problem by refusing to enter into a fiduciary relationship, but this choice would sacrifice the benefits of fiduciary relationships. Another option is to create mandatory disclosure. Licht argues that information asymmetries provide a compelling justification for a strict, full-disclosure-based accountability regime.

Recent work on fiduciary loyalty has sought to understand its content in light of moral understandings of loyalty. Paul Miller indicates that the fiduciary conception of loyalty is different from moral conceptions, and he further argues that it needs to be. Legal and moral loyalties do converge in important respects, and Miller argues that fiduciary loyalty is properly understood as a kind of loyalty. Fiduciary loyalty, however, must be understood in light of the fiduciary relationships in which it figures. By paying attention to this context, we can see that fiduciary loyalties and moral loyalties diverge in several ways. For example, fiduciary loyalty does not ordinarily require loyalty to a beneficiary's entire person as such, but rather to particular ends specified by or for the beneficiary. The enforceability of fiduciary loyalty likewise has bearing on the kind of loyalty it can be. Moral loyalties are often thought to be inconsistent with coercion. Moral loyalties also tend to be more context-dependent than their legal counterparts, and as Miller notes, they tend to have a deeper personal significance. The objects of our 
loyalties - fiduciary and moral - can differ (and frequently do so). Miller's chapter brings out the richness of the relationship between these different categories of loyalty.

\section{LIABILITY AND REMEDIES}

Fiduciary law makes use of distinctive remedies, most notably the disgorgement remedy. Disgorgement is only rarely applied in contract settings, yet it is commonly adopted in response to fiduciary disloyalty. Whatever the merits of an "efficient breach" in other settings, this remedy discourages the practice. To fully understand fiduciary law, we thus need to understand why conflicted fiduciaries must hand over their profits. Yet, while much attention has been focused on disgorgement, there are other remedial features that also shed light on the field. Fiduciary law is a product of equity, and to this day it shows the influence of that jurisdiction. In addition, contract law is not the only private law field that merits comparison to fiduciary law. Fiduciary law can also be compared to tort law, and the relation between these fields is illuminating. The next two chapters offer insights from these additional perspectives.

Samuel Bray's chapter offers a contribution to both the theory of fiduciary remedies and the theory of equity. His analysis focuses on trust law in the US, but, as he notes, the implications are broader. As Bray indicates, punitive damages are widely accepted in the US, and they have been ordered in trust law settings to address fiduciary breaches. This is not to say that such remedies are commonplace, or that every state supports their application. That said, the Restatement understanding is that punitive damages are suited for "the egregious case," and they are a recognizable feature of the legal landscape. In the English Court of Chancery, however, punitive damages were unavailable, and on Bray's account this absence should give us pause. The punitive damages remedy in trust law - to the extent it has been adopted - is an innovation. Bray thus inquires whether punitive damages are justifiable as a trust law remedy. Whether we focus on the plaintiff's rightful position, the goal of optimal deterrence, or the distinctions between law and equity, he argues that the case for a trust law punitive damages remedy has yet to be made.

Much has been said about the connection between fiduciary law and contract law. By contrast, Deborah DeMott's chapter explores the connection between fiduciary law and tort law. As she notes, there are certain cases in which tort liability is dependent on a fiduciary breach by a third party. Sometimes a nonfiduciary participates in another party's fiduciary breach (whether by substantially participating in that breach, or by other means), resulting in tort liability for the party who culpably participates. This type of case can be understood as part of a broader phenomenon. DeMott also explores cases involving wrongful interference with a contract, in governance settings where the contract supplants what would otherwise be a fiduciary obligation. She finds both torts are closely related. Core features include knowledge of the primary wrongdoer's obligations and a causally significant contribution to the wrong suffered. On her account, however, the duties that an accessory actor owes do not simply replicate the duties owed by a primary wrongdoer; they are a specific kind of obligation owed by the accessory actor to the beneficiary. As DeMott argues, the beneficiary has a right not to be mistreated by the accessory actor in this fashion. 


\section{CORPORATIONS}

Directors manage the business and affairs of the corporation. This management role necessarily entails the exercise of discretion, which is widely recognized as an essential aspect of fiduciary relationships. When exercising managerial discretion, directors act as fiduciaries on behalf of the corporation and its stockholders. Different jurisdictions handle these questions in different ways. The Delaware courts present corporate fiduciary law with admirable simplicity: directors and officers owe duties of care and loyalty, and, depending on the facts and circumstances of the case, the courts apply one of three standards to evaluate compliance with these duties: the business judgment rule; enhanced scrutiny; and entire fairness. Even a cursory reading of judicial opinions from Delaware reveals, however, that this simple framing obscures a great deal of nuance in fiduciary regulation. Both chapters on corporate fiduciaries explore these nuances.

Claire Hill and Brett McDonnell's chapter analyzes the problem of structural bias as it relates to corporate law. Corporate directors and officers often come from the same socioeconomic class, and their shared background may influence the way they monitor each other's conduct and the degree of deference that directors pay to officer decisions. It is often thought that this shared background results in less vigorous monitoring. In prior work, Hill and McDonnell have assessed the role that the fiduciary duty of good faith can play in responding to structural bias concerns. Focusing on recent Delaware case law, they now raise doubts about the extent to which fiduciary duties will constrain structural bias - in light of both substantive law and procedural rules. Yet they also suggest that other factors, such as shareholder activism, proxy access, and board diversity, may help to limit this concern. Even so, these counterweights may limit structural bias without necessarily removing it as a problem. As Hill and McDonnell develop, the problems posed by structural bias can be quite complex, and the questions at issue have shifted as both legal and non-legal mechanisms change over time.

Lyman Johnson's chapter brings together three central topics in corporate law: corporate personhood; corporate purpose; and fiduciary duties. Each has received substantial attention in recent years, but not necessarily as a group. Johnson contends that we need to understand how these topics relate to each other, in combination. In his view, corporations have purposes separate and apart from the interests of their shareholders and other constituencies. Directors have fiduciary duties to advance the best interests of the corporation, and these duties are to be understood in terms of the corporation's purposes. Quite possibly, advancing the corporation's purposes will equate to pursuing shareholder wealth maximization. But this will not always be the case, depending on the corporation at issue. Johnson also assesses the relation between these arguments and the recent move to provide for public benefit corporations. In his view, most public benefit corporation laws do not fully achieve a desirable congruence between personhood, purpose, and fiduciary duty. Directors, Johnson argues, should be understood to owe their fiduciary duties to the corporation, and these obligations should be understood in terms of a corporate-centered corporate purpose. 


\section{COMPARATIVE FIDUCIARY LAW}

One of the most fascinating features of modern fiduciary law is the diversity of fiduciary principles across jurisdictions. Although fiduciary law in every jurisdiction is based on a concern over conflicts of interest, the doctrines used to enforce this concern sometimes vary widely. Moreover, different jurisdictions have different approaches to the duty of care. Many fiduciary scholars have used jurisdictional diversity as a motivation for thinking more deeply about the nature of fiduciary relationships and fiduciary duties. Several chapters in this volume use this lens to increase our understanding of fiduciary law.

It is often debated whether - and if so, when - business entities should have the ability to contractually waive fiduciary duties. Christopher Bruner's chapter reviews these questions across jurisdictions, comparing the approaches in the US with those in the UK. For corporate law, we see significant convergence: it is difficult to carve away at fiduciary obligations, but there is room to limit liability risk in some respects. Unincorporated business entities allow for substantially greater contractual freedom to reduce fiduciary duties. Yet there is also divergence. In corporate settings, for example, it is easier to limit liability risk in the US. Interestingly, there is also a notable jurisdictional difference in default fiduciary duties. The limited liability company in Delaware allows for complete elimination of fiduciary duties - but those duties are nonetheless there by default. The UK limited liability partnership, however, provides for an entity with no default fiduciary duties. Bruner assesses the import of the variations across jurisdictions, and proposes that the new UK limited liability partnership may offer a valuable natural experiment.

The duties of corporate directors in the US (Delaware), the UK, and Australia appear similar, with each jurisdiction regulating loyalty and care, but the substance of each duty and the mechanisms to enforce those duties vary widely across jurisdictions. Matthew Conaglen and Jennifer Hill compare these three jurisdictions, focusing special attention on the duty of care and arguing that the collection of doctrines, safe harbors, and enforcement mechanisms regulating director negligence can expand or reduce the gap between standards of conduct and standards of review. In the US, for example, care is an equitable duty that is diminished by the business judgment rule and further weakened by exculpatory clauses in corporate charters. The result is that the duty of care is rarely enforced against corporate directors. In the UK and Australia, by contrast, the duty of care has been codified and is no longer one of "gross negligence." The interaction of these statutory duties with general law and the enforcement regimes in these two jurisdictions are quite different from the US, resulting in different levels of directors' duties in action.

The corporate opportunity doctrine regulates the potential for conflict when a director or officer of a corporation wishes to pursue a business opportunity that might also benefit the corporation and its stockholders. Martin Gelter and Geneviève Helleringer observe that the corporate opportunity doctrine, though fundamental to corporate fiduciary law in both the US and the UK, takes remarkably different forms in those two jurisdictions. In the US, courts focus on whether a business opportunity belongs to the corporation or the fiduciary and offer the interested fiduciary various $e x$ ante opt-outs and ex post defenses for taking an opportunity. In the UK, by contrast, 
fiduciaries are required to avoid any potential conflict of interest and the availability of ex ante opt-outs and ex post defenses for taking an opportunity are limited. Gelter and Helleringer argue that these differences are attributable to the fact that fiduciary law in the US is enforced by courts, whereas fiduciary law in the UK is enforced by monitoring from outside directors and institutional investors.

Many scholars have recently observed the weakening of fiduciary law in various domains. Andrew Tuch suggests that this weakening was essential to the growth and diversification of financial conglomerates in both the US and the UK. Conflicts of interest and conflicts of duty are pervasive in these firms, and strict enforcement of fiduciary standards posed profound challenges for their organizational practices. While these firms attempted to mitigate conflicts through contractual and structural reforms, many wondered if the firms would be required to reduce the size of their operations or even disaggregate their various businesses to avoid fiduciary liability. Nevertheless, financial conglomerates have continued to expand. Tuch contends that the fact that organizations so fraught with conflicts exist supports an intuition that the strength of the loyalty duty has been eroding over time. In this chapter, he provocatively describes the sources of erosion.

\section{PUBLIC FIDUCIARIES}

Public fiduciary theory has a long history, including contributions by John Locke, Thomas Hobbes, and Hugo Grotius. It is also an increasingly important area of study for modern scholars, with a burgeoning literature on its applications. This subject requires us to think closely about what it means to be a fiduciary, given that states and public office holders are different from private actors in significant respects. Public fiduciary theory also requires us to revisit the nature of fiduciary loyalty. What exactly does it mean for the state to be a loyal fiduciary? In this setting, we ordinarily do not have judicial statements defining fiduciary loyalty for us - at least not with respect to the state itself - and so it is important to figure out how private law fiduciary principles relate to fiduciary obligations in the public sphere. Several chapters elaborate on public fiduciary theory and its significance for the law.

The fiduciary theory of the state offers an important extension of fiduciary principles, and recent work in the field has shown an increasing variety of applications. Yet public fiduciary theory is also an area of controversy. Evan Fox-Decent's chapter responds to several of the leading critiques of his account of the fiduciary state. Contrary to some accounts, he argues that public law fiduciary duties bear a close resemblance to their private law counterparts. He also analyzes the problem of multiple beneficiaries. The possibility of conflicting mandates is significant, and Fox-Decent notes that this is a challenge for both public and private fiduciaries. Some critics object that public fiduciary principles are superfluous, given prior agreement on key legal policy questions. Fox-Decent offers detailed examples to refute this claim. In addition, he addresses important questions related to the authority of a fiduciary state. In combination, his arguments provide a nuanced elaboration of public fiduciary principles, and show the versatility of Fox-Decent's approach. 


\section{Research handbook on fiduciary law}

Stephen Galoob's and Ethan Leib's chapter contributes to both the substance and method of fiduciary political theory. They argue for several principles that they contend all fiduciary theorists should accept: a principle of deliberation; a principle of conscientiousness; and a principle of robustness. Galoob and Leib also develop an account of leading methodological approaches to fiduciary theory. For example, a theorist may take a literalist approach, in which case political fiduciary relationships simply are fiduciary relationships. Alternatively, a theorist could take an analogical approach, or a translational approach. As they note, these different approaches need not conflict with each other. They conclude, however, that the potential differences in methodology can also be bypassed, so long as there is agreement on certain core principles of fiduciary political theory. Galoob and Leib argue that a shared appreciation for the principles of deliberation, conscientiousness, and robustness could allow fiduciary political theorists to avoid difficult methodological debates.

If politicians are fiduciaries for the people they represent, are courts competent to enforce fiduciary obligations? Theodore Rave examines various reasons we might question the institutional competence of courts to enforce fiduciary obligations against elected officials: courts do not have the fact-finding capabilities of the legislative or executive branches; courts lack expertise on many of the policy matters that confront the elected branches; and courts whose judges are appointed for life do not have the democratic legitimacy and accountability of the elected branches. Given that many fiduciary cases would involve political judgments, courts may not be the right institutions to say what is in the "public interest" or how best to achieve it. Rave observes, however, that we have similar concerns about courts in the business context, and courts have developed a range of strategies for dealing with those concerns. Analogizing to corporate law, Rave examines strategies for deciding fiduciary issues where courts are ill suited to make first-order decisions about the best interest of the corporation and whether the corporate fiduciaries are faithfully pursuing it. $\mathrm{He}$ concludes that courts can use similar strategies in the political context.

\section{CONCLUSION}

Efforts to unify fiduciary law as a field have paid ample dividends, offering substantial new insights in recent years. At the same time, fiduciary law is a subject that can be viewed from many different angles. There is a reason why some scholars take an atomistic view of fiduciary obligations, or else question whether a single principle can explain fiduciary relationships. Fiduciary relationships show genuine differences from one type to another; loyalty duties vary across settings, both for specific parties and for relationship types (e.g., corporations, trusts, agency relations); and individual jurisdictions each have their own way of conceptualizing what it is to be a fiduciary. Recognizing this should not mean giving up on unity in fiduciary law, but it should encourage a close look at the ways in which the field responds to context.

The chapters in this volume provide this very thing. Some scholars offer new accounts of fiduciary relationships writ large, or offer new ideas on how we should go about explaining fiduciary law. Others turn to the relations between fiduciary loyalty and moral loyalty, between fiduciary relationships and trust, between fiduciary breaches 
and bribery. A number of authors provide innovative accounts of fiduciary obligations, covering their source, scope, and application. There are new perspectives on fiduciary remedies, from an equitable point of view or even from a tort law angle. Various authors give us a comparative law perspective, showing how different features of fiduciary obligations are handled by leading jurisdictions. And several chapters elaborate on the idea of a public fiduciary, demonstrating the richness and versatility of this approach. In combination, these chapters shed new light on a multi-faceted and rapidly growing field of study.

We are hopeful that the range of ideas introduced in this volume will encourage additional research agendas in fiduciary law. Many of the puzzles addressed by these chapters are starting points for further inquiry, and some of the chapters' more controversial arguments are sure to draw responses. The healthy debate we now see over fiduciary principles reflects the status of the field more broadly. Fiduciary law has been a fundamental component of the law for a very long time, but in recent years its significance has become increasingly evident. The chapters in this volume help to show why this subject has drawn so many distinctive points of view. Whether our concerns are public law or private law, legal duties or moral duties, fiduciary law continues to pose new and interesting questions that cut across vital legal topics. We anticipate that this volume will answer some of these questions, even as it raises new ones to consider. 
D. Gordon Smith and Andrew S. Gold - 9781784714833 Downloaded from PubFactory at $04 / 26 / 2023$ 07:14: $01 \mathrm{AM}$ via free access 